Transactions of the American Fisheries Society, v. 132, iss. 6 (Nov. 2003), pp. 10761088.

http://afs.allenpress.com

http://afs.allenpress.com/archive/1548-8659/132/6/pdf/i1548-8659-132-6-1076.pdf Online ISSN: 1548-8659

Print ISSN: 0002-8487

DOI: $10.1577 / \mathrm{T} 02-135$

(C) American Fisheries Society 


\title{
Winter Ecology of Kokanee: Implications for Salmon Management
}

\author{
Geoffrey B. Steinhart*1 and Wayne A. Wurtsbaugh \\ Aquatic, Watershed, and Earth Resources Department and the Ecology Center, \\ Utah State University, Logan, Utah, 84322-5210, USA
}

\begin{abstract}
We sampled various limnological parameters and measured growth and diet of age-0 kokanee Oncorhynchus nerka (lacustrine sockeye salmon) during two winters in a high-mountain lake of the Sawtooth Valley, Idaho. Although winter has been recognized as an important period for many warmwater fishes and for stream-dwelling salmonids, winter limitations have only recently been studied for coolwater and coldwater species. Ice and snow cover in winter limited light penetration. As a result, chlorophyll- $a$ and zooplankton density were lower in ice-covered periods than during ice-free periods. The weight of stomach contents was often below a maintenance ration, yet the incidence of empty stomachs was extremely low (1 of 63) and the weight of stomach contents increased as energy reserves declined, indicating that kokanee were actively foraging during winter. Kokanee length and weight remained constant during the winter of 1993-1994 but increased from November through May in 1994-1995. Condition factors, however, declined significantly over the winter in both years, and lipid content approached levels associated with mortality. Differences in growth patterns may have been caused by a combination of changes in zooplankton density and kokanee abundance and in kokanee behavior to defend energy reserves or avoid predation. Results demonstrated the ambiguity of some growth measurements and the importance of choosing the correct metric for measuring growth in fishes. Because juvenile kokanee and sockeye salmon are ecologically similar, management efforts to restore the endangered Snake River sockeye salmon to the Sawtooth Valley lakes should recognize that winter conditions might be a bottleneck for this species.
\end{abstract}

Winter can be a critical period for many fishes because cold temperatures and reduced productivity can limit survival (Toneys and Coble 1979; Miranda and Hubbard 1994). Identifying mechanisms underlying winter mortality is essential to understanding recruitment and population dynamics of fishes. For young fish, winter mortality is often the result of starvation, predation, or osmoregulatory failure (Toneys and Coble 1979; Miranda and Hubbard 1994). Significant lipid losses, a consequence of starvation, during winter have been documented in sand smelt Atherina boyeri (Henderson et al. 1988), smallmouth bass Micropterus dolomieu (Oliver and Holeton 1979), largemouth bass $M$. salmoides (Ludsin and DeVries 1997) Colorado pikeminnow Ptychocheilus lucius (Thompson et al. 1991), and many other species. Lipid loss in age-0 fish, owing to their high metabolic demands, may be so severe as to cause mortality (Shuter and Post 1990). Size-selective mortality (i.e., small individuals dying) has been documented for many fishes and may control year-

\footnotetext{
* Corresponding author: steinhart.3@osu.edu.

1 Present address: Aquatic Ecology Laboratory, The Ohio State University, 1314 Kinnear Road, Columbus, Ohio 43212-1156, USA.
}

Received September 20, 2002; accepted March 25, 2003 class strength (Toneys and Coble 1979; Henderson et al. 1988; Miranda and Hubbard 1994). Even for coldwater species such as salmonids, winter can be an extremely harsh period (Cunjak 1988; Metcalfe and Thorpe 1992).

Winter growth rate and lipid loss affect not only overwinter survival but also the behavior, future survival, and choice of life history tactics in salmon. Most young fish rely on energy stores to meet metabolic demands in winter, but when lipid content declines, salmon show increased appetite (i.e., increased consumption) and foraging activity (Metcalfe and Thorpe 1992; Kadri et al. 1996; Maclean and Metcalfe 2001). Increased foraging activity can reduce dependence on limited energy reserves, but it increases predation risk (Dannewitz and Petersson 2001; Reinhardt 2002). If winter conditions or energy reserves do not allow salmon to reach adequate size or lipid content by spring, postwinter mortality may increase owing to metabolic demands of smoltification and $\mathrm{mi}-$ gration (Hoar 1976; Rondorf et al. 1985; Jonsson and Jonsson 1998). Smolt-to-adult survival improves with increased size and condition of smolts (Holtby et al. 1990; Henderson and Cass 1991). In addition, the timing and expression of smoltification and maturation are at least partially controlled by size and energy stores (Rowe et al. 1991; 
Berglund 1995; Duston and Saunders 1999; Rikardsen and Elliot 2000). Poor condition shortened the spawning migration some individuals in a population of Atlantic herring Clupea harengus (Slotte 1999), whereas low lipids halted the migration of silver-stage Euorpean eels Anguilla anguilla (Svedäng and Wickström 1997).

Winter conditions are especially important for salmon in lakes at high latitudes or in high mountains, such as the lakes of the Sawtooth Valley of central Idaho. Historically, five lakes in the valley supported Snake River populations of sockeye salmon Oncorhynchus nerka, kokanee (lacustrine sockeye salmon) or both (Bjornn et al. 1968). Life history tactics distinguish sockeye salmon and kokanee: kokanee spend their entire life in freshwater, but sockeye salmon migrate to the ocean at age 1 or 2 and return 1-3 years later to their natal stream to spawn as adults (Burgner 1992). Unlike many warmwater species, $O$. nerka (we will use $O$. nerka when referring collectively to sockeye salmon and kokanee) are active at temperatures below $4^{\circ} \mathrm{C}$, so winter is not a period of dormancy (Burgner 1992). In fact, at $4^{\circ} \mathrm{C}$, sockeye salmon must consume about $0.1 \%$ of their wet weight per day to meet basic metabolic requirements (Brett et al. 1969). Due to low zooplankton abundance, however, fewer than $2 \%$ of sockeye salmon in a coastal Alaskan lake consumed food during winter (Ruggerone 1992). Even in a eutrophic coastal system such as Lake Washington, declining energy reserves caused juvenile sockeye salmon to become more active in late winter than in early winter (Eggers 1978). Unlike coastal lakes, many O. ner$k a$ systems, including the Sawtooth Valley lakes, are ice covered for more than half the year. Ice cover reduces light penetration and photosynthesis, which, in turn, limit winter productivity and $O$. nerka foraging ability (Steinhart and Wurtsbaugh 1999).

Understanding winter conditions in the Sawtooth Valley lakes may provide insight into the recruitment success of Snake River sockeye salmon. Snake River sockeye salmon declined to such low numbers that they were listed as an endangered species in 1991. Sockeye salmon smolts from the Snake River travel over $1,400 \mathrm{~km}$ and pass eight hydroelectric dams en route to the ocean. Each dam may delay migration by a week or more and increase a smolt's exposure to piscivorous fish (Venditti et al. 2000; Budy et al. 2002). Not only is this one of the longest seaward migrations among sockeye salmon populations, but migration begins before ice-out, so there is little time for them to build lipid reserves before smoltification (Bjornn et al. 1968). Many fishes deplete lipids during migration; thus, increased energetic costs of migration could reduce survival or even prevent migration (Rondorf et al. 1985; Svedäng and Wickström 1997; Leonard and McCormick 1999).

Efforts are currently underway to augment the remnant populations of sockeye salmon in three Sawtooth Valley lakes, but all five lakes contain self-sustaining populations of kokanee. Although they usually have different life histories, kokanee can migrate to the ocean and have established anadromous populations in lakes previously devoid of sockeye salmon (Taylor et al. 1996; Quinn et al. 1998). In fact, kokanee may have been responsible for the return of sockeye salmon to the Sawtooth Valley lakes after a dam entirely blocking access to the ocean was breached in 1934 (Bjornn et al. 1968). Sockeye salmon, however, sometimes remain in freshwater for their entire life (Ricker 1938), and it is now believed that these "residual" sockeye salmon (i.e., another freshwater resident that differs from kokanee) in the Sawtooth Valley lakes gave rise to the current anadromous population.

We sought to understand what influenced the winter growth and condition of kokanee in Stanley Lake, in the Sawtooth Valley, and how that might affect the recovery of the Snake River sockeye salmon. Because Snake River sockeye salmon were not present during our study, we used kokanee as a surrogate. Sockeye salmon and kokanee eat similar food (Wood et al. 1999), undergo comparable smoltification processes (Foote et al. 1992, 1994; Rice et al. 1994), and are more closely related to each other within a lake than between lakes (Foote et al. 1989; Taylor et al. 1997). Specifically, we quantified kokanee length, weight, and energetic content from November through May and examined how those variables related to zooplankton abundance and kokanee behavior.

\section{Methods}

Study site.-Stanley Lake, located in the Snake River drainage in the Sawtooth Valley of central Idaho $\left(44^{\circ} \mathrm{N}, 115^{\circ} \mathrm{W}\right)$ at an altitude of $1,985 \mathrm{~m}$, is typically ice covered from late November until early May. It covers 81 ha and has mean and maximum depths of 13 and $26 \mathrm{~m}$. During our study, the fish community of Stanley Lake was predominated by kokanee and lake trout Salvelinus namaycush but also included cutthroat trout $O$. clarki, rainbow trout $O$. mykiss, brook trout $S$. fontinalis, 
mountain whitefish Prosopium williamsoni, northern pikeminnow $P$. oregonensis, suckers Catostomus spp., redside shiner Richardsonius balteatus, dace Rhinichthys spp., and sculpin Cottus spp. (Taki and Mikkelsen 1997). We sampled limnological characteristics and the kokanee population monthly during October-May and every 2 weeks during June-September 1993-1995.

Limnological sampling.-On each sampling date, we sampled three stations near the center of Stanley Lake, where depth exceeded $23 \mathrm{~m}$. During ice cover, we cut holes with an ice auger or a chainsaw. We measured temperature and dissolved oxygen (1-m intervals to $10 \mathrm{~m}$, and every $5 \mathrm{~m}$ below $10 \mathrm{~m}$ ) using either a YSI model 58 dissolved oxygen meter (November through May) or a Hydrolab Surveyor III meter (June through October). Light intensity (photosynthetically active radiation 400-700 nm) was measured with a submersible Li-Cor Model LI-188B radiometer. The probe was lowered at $1-\mathrm{m}$ intervals to the bottom of the lake or until light was undetectable $\left(<0.02 \mathrm{~W} / \mathrm{m}^{2}\right)$. A surface light sensor corrected for changes in surface intensity due to cloud cover. During ice cover, the light sensor was lowered through a $0.75-\mathrm{m}^{2}$ hole. To avoid light contamination from the hole, we extended the sensor $3 \mathrm{~m}$ laterally from the hole and filled the hole with snow. We collected water samples (0-6 m and $23 \mathrm{~m}$ ) for chlorophyll- $a$ analysis; two replicate $50-\mathrm{mL}$ aliquots per sample were filtered through $0.45-\mu \mathrm{m}$ cellulose acetate filters and frozen. Filters were placed in $6 \mathrm{~mL}$ of $100 \%$ buffered methanol, extracted for $24 \mathrm{~h}$ and analyzed with a Turner model 111 fluorometer to within \pm $0.1 \mu \mathrm{g}$ cholorophyll $a / \mathrm{L}$ (Holm-Hansen and Riemann 1978). We collected zooplankton at each station with an $80-\mu \mathrm{m}$ mesh closing conical net (35 $\mathrm{cm}$ diameter and $150 \mathrm{~cm}$ long), equipped with a General Oceanics flowmeter. Samples were immediately preserved in $10 \%$ formalin-sucrose solution and subsequently identified, counted, and measured. Zooplankton densities were corrected for the volume of water samples, and dry biomass was calculated using length-weight regressions (McCauley 1984; Koenings et al. 1987).

Fish sampling.-Kokanee were collected monthly from November to May with a combination of trawls and gill nets. In November and May, when the lake was ice-free, we collected kokanee at or near the dark phase of the moon using a midwater beam trawl (3 $\mathrm{m}$ wide, $7 \mathrm{~m}$ deep). Oblique trawl hauls, $30 \mathrm{~min}$ in duration at a speed of about $1 \mathrm{~m} / \mathrm{s}$, were made at various depths from the surface to $20 \mathrm{~m}$. In May of 1994 and 1995, and during periods of ice cover, we used sinking horizontal gill nets (each with three panels of square mesh: 22, 27, and $35 \mathrm{~mm}$ ), floating horizontal gill nets (each with four panels of square mesh: 25, 32, 38, and $44 \mathrm{~mm}$ ), and vertical gill nets $25 \mathrm{~m}$ deep by $3 \mathrm{~m}$ wide (each with one panel of square mesh: 19, 25, or $38 \mathrm{~mm}$ ) set in holes cut by chainsaw (Hubert 1996). Initial sampling revealed that few kokanee were captured during daylight, so gill nets were set for 24-h and checked between 0800 and 1000 hours. After capture, we measured maximum total length (TL; nearest $\mathrm{mm}$ ) and wet weight (WW; nearest $0.01 \mathrm{~g}$ ) and saved individuals for gut and otolith analyses.

Kokanee less than $150 \mathrm{~mm}$ TL were considered to be age 0 , graduating to age 1 on 1 January. This size threshold is appropriate because September trawling in Stanley Lake revealed age-0 kokanee to be $75 \mathrm{~mm}$ mean TL (range, 35-97 $\mathrm{mm}$ ) and age 1 to be $161 \mathrm{~mm}$ (range, 111-179 mm; Paul Kline, Idaho Department of Fish and Game, unpublished data). Using a threshold of $150 \mathrm{~mm}$, the mean TL of age-0 kokanee in Stanley Lake in November was $113 \mathrm{~mm}$ (range, 71-135 $\mathrm{mm}$ ), well below the age-1 September mean total length.

Kokanee condition.-We calculated relative condition (Kn; Anderson and Neumann 1996) using population-specific coefficients from the length-weight regression for all captured kokanee (i.e., we included kokanee $>150 \mathrm{~mm}$ TL):

$$
\begin{gathered}
\text { wet weight }=4 \times 10^{-6} \cdot\left(\mathrm{TL}^{3.11}\right) \\
\qquad\left(r^{2}=0.99 ; N=329\right)
\end{gathered}
$$

To determine dry weight (DW), fish were thawed, cut into pieces, and dried for $24 \mathrm{~h}$ at $60^{\circ} \mathrm{C}$ (i.e., a temperature that will not oxidize fats; Kerr et al. 1982). Lipids were quantified by Soxhlet lipid extraction, using petroleum-ether as a solvent to preserve structural fats (Bligh and Dyer 1959). After drying, lipids were extracted from individual fish for $24 \mathrm{~h}$. Because lipid content is related to fish size, we used residual lipid weights to avoid confounding effects of fish size (Sutton et al. 2000). Residual lipid weight (RLW) was calculated as the difference between observed lipid weight (LW) and predicted LW from the regression:

$$
\begin{gathered}
\log _{10}(\mathrm{LW})=3.301 \cdot \log _{10}(\mathrm{TL})-6.931 \\
\left(r^{2}=0.49 ; N=191\right) .
\end{gathered}
$$

We compared the between-year variation of kokanee pre- and postwinter with respect to TL, WW, $\mathrm{Kn}$, and RLW with $t$-tests $(\alpha=0.05)$ and examined 
TABLE 1.-Average limnological conditions during ice-free (mid-May through early November) and ice-covered periods (December-April) in Stanley Lake, Idaho. Surface temperature was measured at $0 \mathrm{~m}$, surface chlorophyll $a$ was the mean from 0-6 m, hypolimnetic chlorophyll $a$ was at $1 \mathrm{~m}$ above the bottom (typically $25 \mathrm{~m}$ ), and zooplankton were collected from the surface to the bottom.

\begin{tabular}{llccccc}
\hline & & \multirow{2}{*}{$\begin{array}{c}\text { Surface } \\
\text { temperature }\end{array}$} & $\begin{array}{c}\text { Depth of } \\
\text { Year(s) }\end{array}$ & Season & & \multicolumn{2}{c}{ Chlorophyll $a(\mathrm{mg} / \mathrm{L})$} & \multirow{2}{*}{$\begin{array}{c}\text { Zooplankton } \\
(\mu \mathrm{C})\end{array}$} & $1 \%$ light $(\mathrm{m})$ & Surface & Hypolimnetic & \\
\hline 1993 & Ice free & 11.1 & 14.40 & 1.26 & 0.91 & 18.3 \\
$1993-1994$ & Ice covered & 3.6 & 3.85 & 0.92 & 0.12 & 2.35 \\
1994 & Ice free & 14.1 & 14.95 & 0.52 & 1.1 & 22.71 \\
$1994-1995$ & Ice covered & 3.7 & 5.30 & 0.55 & 0.08 & 11.32 \\
\hline
\end{tabular}

changes among months within a year and between years with analysis of covariance (ANCOVA).

Kokanee diet.-Gut contents were collected from just 63 of the 217 kokanee captured because we randomly selected individuals for other experiments and we did not sample diets from fish that clearly had been in the gill net for an extended period (e.g., discolored or stiff). Kokanee used for diet analyses were placed on wet ice, and lavage without dissection was conducted with a waterfilled syringe within $2 \mathrm{~h}$. Stomach contents were preserved in 95\% ethanol and subsequently identified, counted, and measured. We calculated the total undigested-weight of ingested prey based on zooplankton length-weight regressions (McCauley 1984; Koenings et al. 1987). At winter lake temperatures near $4^{\circ} \mathrm{C}, O$. nerka take over $24 \mathrm{~h}$ to digest $75 \%$ of their stomach contents (Brett et al. 1969). Although back-calculated weights may underestimate total ration somewhat, such a slow digestion rate should still provide insight into changes in daily ration.

Using bioenergetic simulations (Hewett and

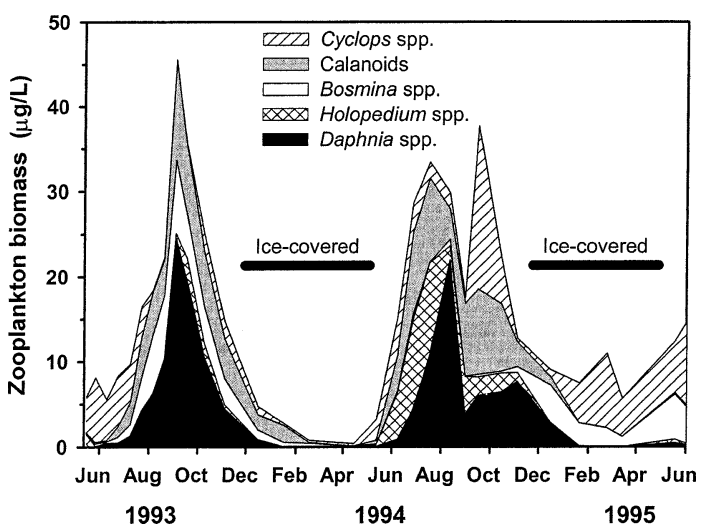

FIGURE 1.-Seasonal patterns of crustacean zooplankton biomass in Stanley Lake, Idaho, from 1993 to 1995. Data do not include copepod nauplii, which were not found in kokanee diets during this study.
Johnson 1992), we predicted prey consumption that matched observed changes in wet weight and estimated changes in caloric density during November through May. Model parameters included bioenergetic equations for kokanee (Beauchamp et al. 1989) and observed water temperatures (assuming $O$. nerka were at $10 \mathrm{~m}$; Steinhart and Wurtsbaugh 1999). Copepods were the primary food ( $61 \%$ by weight) of kokanee in both years (Steinhart 1997), and we estimated of copepod energy density to be $2.5 \mathrm{~kJ} / \mathrm{g}$ (Hewett and Johnson 1992). Monthly kokanee energy density was estimated using energy densities for protein $(24 \mathrm{~kJ} /$ $\mathrm{g})$, lipid $(40 \mathrm{~kJ} / \mathrm{g})$, and carbohydrates $(17 \mathrm{~kJ} / \mathrm{g}$; Brett et al. 1969). Lipid weight was measured directly, carbohydrate weight was estimated as $2 \%$ of kokanee wet weight, and protein weight was the difference (Brett et al. 1969).

\section{Results}

\section{Limnology}

Snow and ice (0.4-0.8 m thick) covered Stanley Lake from late November until early May in both years, and blocked up to $99 \%$ of incident light from reaching the water. Reduced light penetration and low temperatures during ice cover produced hypolimnetic chlorophyll- $a$ concentrations 9-12 times lower than at ice-free periods (Table 1). Surface (0-6 m) chlorophyll $a$ did not vary seasonally; photoinhibition limited production in surface waters during ice-free periods (Gross et al. 1998). Dissolved oxygen levels were sufficient to support salmon $(>5 \mathrm{mg} / \mathrm{L})$ through most of the water column; however, on occasion, oxygen levels fell below $5 \mathrm{mg} / \mathrm{L}$ at 15 to $25 \mathrm{~m}$.

Zooplankton biomass during ice-free months exceeded that during ice cover (Table 1; Figure 1) by sixfold in 1993-1994 and by twofold in 19941995. During ice-free periods, Daphnia spp. were the most abundant zooplankton, but cyclopoid copepods and Bosmina spp. predominated during ice 


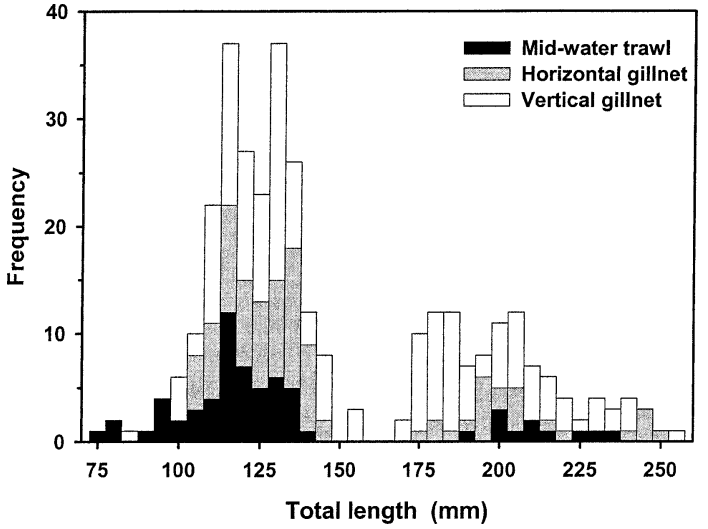

FIGURE 2.-Stacked-bar histogram of the total-length frequencies of three different collection techniques (midwater trawl, horizontal gill net, vertical gill net) used to capture kokanee in Stanley Lake, Idaho, during November-May of 1993-1995. All kokanee less than $150 \mathrm{~mm}$ total length were assumed to be age 0 during November-December and age 1 during January-May.

cover. Mean zooplankton biomass from May to November was 25\% higher in 1994 than 1993, and during ice cover, mean zooplankton biomass was five times higher in 1994-1995 than in 1993-1994 (Table 1).

\section{Kokanee Growth}

Kokanee $(<150 \mathrm{~mm}$ TL) captured in trawls, horizontal gill nets and vertical gill nets were similar in length, although the trawl caught more small kokanee than did the gill nets (Figure 2). Total length of kokanee caught in horizontal and vertical gill nets did not differ significantly (KolmogorovSmirnov [KS] test: $D=0.15, P=0.37$; Sokal and Rohlf 1981), so catches from these two net types were combined. The midwater trawl caught different kokanee sizes than gill nets (KS test: $D=$ $0.22, P=0.04$ ), but the difference was due to a few small kokanee captured in the trawls (Figure 2 ). If the four smallest kokanee were removed, there was no difference between the trawl and combined gill-net distributions (KS test: $D=0.12$, $P=0.66)$. Therefore, we combined all catches because our comparisons between months were not heavily biased by collection method, especially considering that trawls were used in both November and May and that residual lipid weight analysis corrected for possible TL biases.

Kokanee did not grow from November to May in 1993-1994 but did grow over the winter of 1994-1995 (Table 2; Figure 3). Kokanee were similar in length $(t=0.81, \mathrm{df}=43, P=0.42)$ and weight ( $t=1.04$, df $=45, P=0.30)$ in November of both years but grew more during the winter of 1994-1995 than in 1993-1994. Although kokanee lengths in May were not significantly different between years $(117 \mathrm{~mm}$ versus $126 \mathrm{~mm} ; t=1.65$, df $=16, P=0.06$ ), mean kokanee wet weights were $3 \mathrm{~g}$ heavier after the winter of 1994-1995 $(t=1.7, \mathrm{df}=17, P=0.05)$ and ANCOVA results show that kokanee TL and wet weight increased during 1994-1995 (Table 2). Wet weight did not increase proportionately with TL, as evidenced by significant declines in condition factor in both years (Table 2; Figure 3). Kokanee condition factors in November were significantly higher in 1994 than in $1993(t=2.64$, df $=34, P=0.01)$, but condition factors converged by May $(t=0.77$, df $=16, P=0.45$ ).

Although kokanee grew in both length and weight in 1994-1995, their RLW declined during November through May in both years (Table 2; Figure 3). Kokanee began with 50\% lower RLW in November 1993 than in November $1994(t=$ 2.54 , df $=9, P=0.032$ ), but in each year, RLW had converged to similarly low values by May $(t=$ $1.10, \mathrm{df}=10, P=0.30)$. Month had a significant effect on RLW, and there was a significant difference between years (Table 2). Owing to changes in wet weight and RLW, calculated mean energy content of kokanee declined from 89 to $55 \mathrm{~kJ}$ over

TABLE 2.-Analysis of covariance results of kokanee growth parameters from Stanley Lake, Idaho. Year columns contain regression coefficients and statistics for individual ice-covered seasons; sample month was the independent variable. Year comparison presents month-year interactions, significant values (in bold) indicating that measured growth rates differed between years. Abbreviations: $\mathrm{TL}=$ total length, $\mathrm{WW}=$ wet weight, $\mathrm{Kn}=$ residual condition factor, and RLW = residual lipid weight. Sample sizes are presented in Figure 3.

\begin{tabular}{|c|c|c|c|c|c|c|c|c|}
\hline \multirow{2}{*}{$\begin{array}{l}\text { Growth } \\
\text { parameter }\end{array}$} & \multicolumn{3}{|c|}{ 1993-1994 } & \multicolumn{3}{|c|}{ 1994-1995 } & \multicolumn{2}{|c|}{ Year comparison } \\
\hline & Slope & $t$ & $P$ & Slope & $t$ & $P$ & $F$ & $P$ \\
\hline TL & 1.26 & 1.56 & 0.12 & 2.70 & 5.59 & $<0.001$ & 2.46 & 0.12 \\
\hline WW & 0.18 & 0.77 & 0.44 & 0.78 & 5.35 & $<\mathbf{0 . 0 0 1}$ & 4.93 & 0.027 \\
\hline $\mathrm{Kn}$ & -0.02 & -3.69 & $<\mathbf{0 . 0 0 1}$ & -0.01 & -2.96 & 0.004 & 0.56 & 0.46 \\
\hline RLW & -0.05 & -4.95 & $<\mathbf{0 . 0 0 1}$ & -0.08 & -20.30 & $<\mathbf{0 . 0 0 1}$ & 13.27 & $<\mathbf{0 . 0 0 1}$ \\
\hline
\end{tabular}



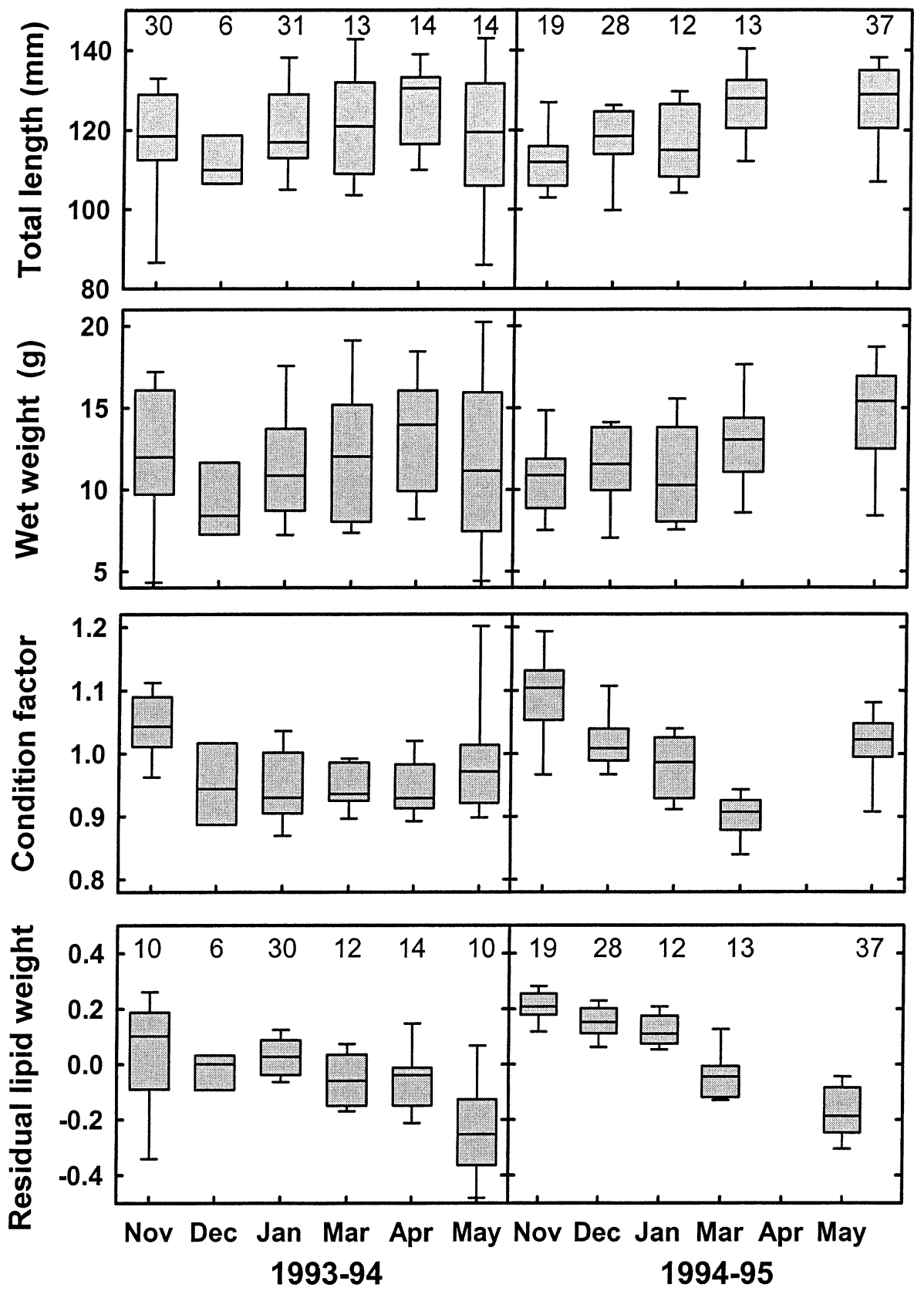

FIGURE 3.-Changes in mean total length, wet weight, condition factor, and residual lipid weight for kokanee from Stanley Lake, Idaho, over the winters of 1993-1994 and 1994-1995. Whiskers represent the 10th and 90th percentiles, the boundaries of the boxes indicate the 25 th and 75 th percentiles, and the bars indicate the medians. Sample sizes for total length, wet weight, and condition factor are presented in the top panels, and sample sizes for residual lipid weight are presented in the bottom panels.

the winter of 1993-1994 but only declined from 89 to $85 \mathrm{~kJ}$ in $1994-1995$.

Observed growth patterns may have been confounded by size-selective overwinter mortality, so we compared November TL quantiles to May TL quantiles $(5,10,25,50,75,90$, and 95) and looked for size-selective mortality or growth (Figure 4; for detailed methods and interpretation, see Post 


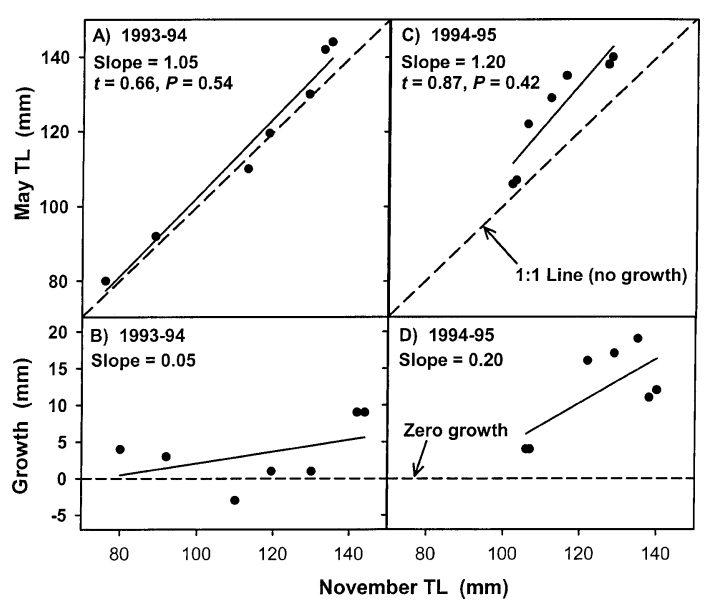

FIgURE 4.-Quantile-quantile (QQ) and growth increment plots for kokanee over the winters of 19931994 and 1994-1995 in Stanley Lake, Idaho. If kokanee grew from November to May, points on the QQ plots (panels $\mathbf{A}$ and $\mathbf{C}$ ) fall above the 1:1 line. Growth increment plots (panels B and D) show the magnitude of growth for each November's total length (TL) quantile. The slopes of the QQ plots indicated that no size-selective processes occurred $\left(H_{0}\right.$ : slope $=1$; Post and Evans 1989). Likewise, no size-selective processes are indicated in the growth increment plots $\left(H_{0}\right.$ : slope $=0 ; t$ and $P$ statistics are identical to QQ plots).

and Evans 1989). Growth increments were greater during 1994-1995 than 1993-1994, which corroborated our ANCOVA results that kokanee grew only during the 1994-1995 winter. Size-selective processes did not affect Stanley Lake kokanee in 1934-1994 winter. Slopes of TL quantile-quantile (QQ) and growth increment plots, along with no change in size, demonstrate that neither size-selective mortality nor size-selective growth occurred (case 1 in Post and Evans 1989). The QQ plot and growth increment slopes suggest that either no size-selective processes operated in 19941995 (case 4) or that a combination of size-selective growth (small $<$ large) and size-selective mortality (for small or large individuals; cases $8 \mathrm{~b}$ and $9 \mathrm{~b}$ in Post and Evans 1989) may have been produced the apparent growth.

There was a strong relationship between total length, percent water, and percent lipid for kokanee (Figure 5). We derived the following multiple regression, which may be used for to estimate percent lipid in kokanee from populations other than Stanley Lake:

$$
\begin{aligned}
\text { percent lipid }= & 73.8-0.85 \cdot(\text { percent water }) \\
& -0.03 \cdot \mathrm{TL} \\
& \left(r^{2}=0.93 ; N=341\right) .
\end{aligned}
$$

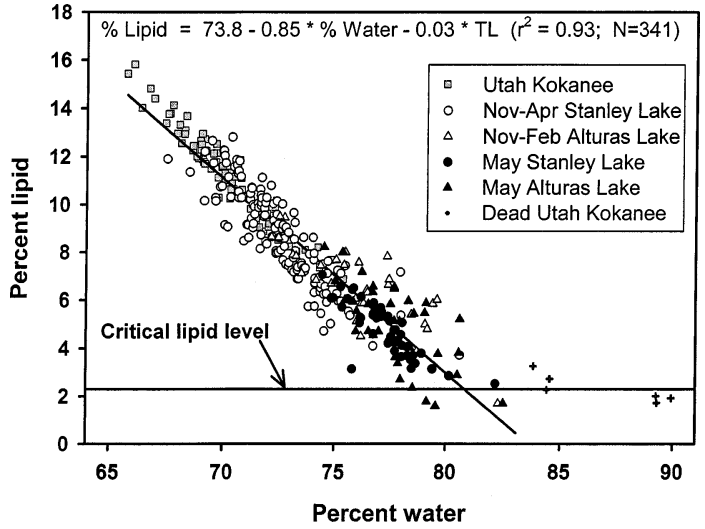

FIGURE 5.-Kokanee lipid content (percent of wet weight) as a function of percent water. Data are for kokanee captured in Stanley and Alturas lakes, Idaho, as well as for kokanee from a Utah hatchery. The critical level is the mean percent lipid of kokanee that died due to starvation (points indicated by plus signs were not used in the multiple regression). Although the graph only shows the relationship between water content and lipids, total length (TL) also had a significant $(P<0.0001)$ influence on lipids.

Both percent water and total length were significant factors $(P<0.0001)$ in the regression equation. Sources of these data used for this regression analyses were (1) Stanley Lake (this study), (2) kokanee collected from a second Sawtooth Valley lake (Alturas Lake) by midwater trawl and gill nets in 1993-1995 (Steinhart 1997), and (3) kokanee obtained from a Utah hatchery (original stock source was Lake Whatcom, Washington, but these offspring were progeny of parents stocked into Flaming Gorge Reservoir, Utah). Six of the Utah kokanee were subjected to a food-deprivation experiment and died with a mean lipid content of 2.3\% (Steinhart 1997). Field lipid values measured in kokanee from Stanley and Alturas lakes in May 1994 and 1995 approached this critical lipid content (Figure 5).

\section{Kokanee Diet and Bioenergetics}

The mean weight of kokanee stomach contents was extremely low between early and mid winter, but it increased as lipid content decreased in late winter (Figure 6). Light limited foraging ability when Stanley Lake was ice covered (Steinhart and Wurtsbaugh 1999), but during the ice-free months of November and May, kokanee consumed less prey when their energy reserves were high (November) than when lipids were nearly exhausted (May). Regurgitation may have occurred in some kokanee taken by gill nets, but that did not appear 


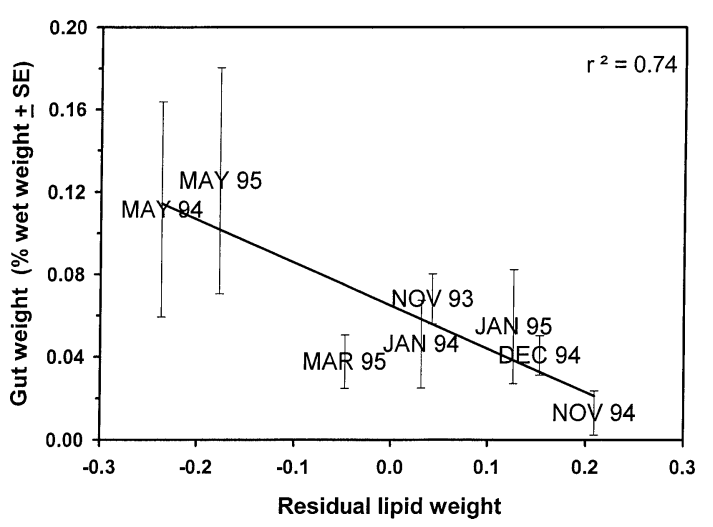

FIGURE 6.-Relationship between mean weight of gut contents and residual lipid weight of kokanee captured during November-May, 1993-1995, in Stanley Lake, Idaho $\left(r^{2}=0.74 ; P<0.006\right)$. Note that gut weight generally increased from November to May in each year, whereas residual lipid weight decreased.

to overly bias our results because the lowest gut weights were found in kokanee caught during November trawl sampling. In addition, May samples included fish taken by both gill nets and trawls, and were the only samples in which the weight of the stomach contents exceeded the estimated maintenance ration for $O$. nerka at $4^{\circ} \mathrm{C}(0.1 \%$ wet weight/d; Brett et al. 1969). Sixty-two of 63 stomachs examined between November 1993 and May 1995 contained prey, suggesting that kokanee were actively feeding during our sampling. Observed kokanee consumption (Figure 6) was similar in 1993-1994 and 1994-1995 during both ice covered $(t=0.08$, df $=29, P=0.94)$ and the icefree periods in November and May $(t=0.25$, df $=33, P=0.80$ ).

From the bioenergetics simulations, the predicted kokanee consumption rate was 53\% higher in 19941995 than in 1993-1994. From November 1993 to May 1994, kokanee consumed an average of 0.017 $\mathrm{g}$ of zooplankton/d, or $0.14 \%$ of their wet weight/ $\mathrm{d}$ (near their maintenance ration of $0.1 \% \mathrm{WW} / \mathrm{d}$; Brett et al. 1969). In 1994-1995, average kokanee consumption was $0.026 \mathrm{~g}$ of zooplankton/d $(0.21 \%$ $\mathrm{WW} / \mathrm{d})$. Consumption differences were reflected in energy loss rates. From November 1993 to May 1994, kokanee energy content declined at an estimated $175 \mathrm{~J} / \mathrm{d}$, but during 1994-1995, when zooplankton densities were higher, energy content declined at $20 \mathrm{~J} / \mathrm{d}$.

\section{Discussion \\ Kokanee Growth during Winter}

In Stanley Lake kokanee, percent lipid and estimated energetic content declined during both winters. Length and weight changes, however, differed among winters; in 1993-94, kokanee did not grow in length or weight but they did in 19941995. May lipid levels converged in both years at levels approaching the critical limit where mortality may occur. The lipid levels in May were similar to values when Colorado pikeminnow die (Thompson et al. 1991) and, when the only remaining lipids are structural, in Chinook salmon O. tshawytscha (Rondorf et al. 1985). Although we could not rule out the possibility of size-selective growth or mortality in 1994-1995, we found no size-dependent changes in 1993-1994. Given the small size of age-0 kokanee compared with their lake trout predators, it is reasonable that size-dependent predation was not an important factor. Therefore, we believe that kokanee growth patterns during winter may be explained by different prey abundances and behavioral changes to conserve limited energy reserves. Limited prey abundance during winter may be accentuated by reduced foraging ability resulting from low light penetration through ice and snow covering the lake (Steinhart and Wurtsbaugh 1999).

Growth of sockeye salmon and kokanee is often density dependent and related to zooplankton density (Hyatt and Stockner 1985; Rieman and Meyers 1992). In 1994, kokanee condition factor and lipid content in November were higher than in 1993, which may have been the combined result of $25 \%$ more zooplankton and $75 \%$ fewer kokanee during ice-free periods in 1994 (Taki and Mikkelsen 1997). In addition, kokanee grew more (in TL and WW) and their predicted November-May consumption was greater for 1994-1995, when mean zooplankton biomass was five times greater, than it was in 1993-1994. These results suggest that zooplankton abundance can limit the growth of Stanley Lake kokanee in winter and that competition with abundant $O$. nerka may further limit growth (Taki and Mikkelsen 1997).

The weight of kokanee gut contents increased as lipid content decreased. It is presumed that the weight of gut contents can be used as a proxy for appetite (Metcalfe and Thorpe 1992) or food availability. Increased appetite with decreasing energy stores occurs in Atlantic salmon Salmo salar (Metcalfe and Thorpe 1992; Silverstein et al. 1999), brown trout Salmo trutta (Dannewitz and Petersson 2001), and Arctic char Salvelinus alpinus (Jobling and Miglavs 1993). Furthermore, the timing of life history events affects appetite, growth rate, and behavior (Thorpe 1987; Metcalfe 1998). For example, when Atlantic salmon fry were split into 
two groups beginning in their first summer; the larger fry fed throughout the winter in preparation for smolting in the spring, whereas the smaller fry fed less, were less active, and smolted 1 year later. The behavior of the small fry reduced predation risk over the winter, although both groups of fish still showed increased appetites and activity when energy reserves declined (Metcalfe and Thorpe 1992; Kadri et al. 1996).

Although kokanee do not typically migrate to the ocean, they do undergo many of the physical changes involved with smoltification and maturation (Foote et al. 1992, 1994; Rice et al. 1994). Both processes require energy and can be stressful (Hoar 1976); therefore, kokanee must be physically prepared before undertaking these changes. In 1993-1994, kokanee entered the winter with less energy than in 1994-1995, and their behavior could be compared with the smaller Atlantic salmon fry in the above example. Kokanee in 19931994 did not grow over winter, possibly because of limited zooplankton availability. A combination of reduced light penetration and low zooplankton density reduced kokanee foraging ability during winter, and as a result, kokanee may have foregone growth to adopt behaviors (e.g., diel vertical migration) that reduced predation risk from piscivores (Steinhart and Wurtsbaugh 1999). Conversely, in 1994-1995, kokanee were in better condition and may have foraged more actively (as indicated by bioenergetics consumption estimates) but still declined in condition because they utilized their energy reserves to continue growth and, perhaps, to hasten smolting and maturation, or avoid predation. Morgan et al. (2000) suggested that adding mass is easier than increasing skeletal growth, so if rapidly attaining a large size confers advantages in this population, then diverting lipid stores for growth in length during winter could be beneficial, at least until lipids were nearly exhausted. In summer, when light and zooplankton are not as limiting as during ice-covered periods, the larger kokanee then would be well prepared to add mass or lipid stores.

\section{Implications for Snake River Sockeye Management}

In both study years, kokanee had difficulty meeting their daily maintenance ration due to low zooplankton density and reduced light intensity during periods with ice cover (Steinhart and Wurtsbaugh 1999). As a result, kokanee reached lipid levels approaching lethal limits. This result could have important implications for endangered Snake Riv- er sockeye salmon recovery efforts. Smolts leaving the Sawtooth Valley are some of the largest of any sockeye salmon system (Bjornn et al. 1968; Taki and Mikkelsen 1997), and they must undergo a $1,400-\mathrm{km}$ migration. This arduous migration may explain why smolts traditionally left the Sawtooth Valley lakes at such a large size. Changes along this migration route, specifically the addition of eight dams, have made this journey more perilous (Budy et al. 2002). Therefore, to successfully restore the Snake River sockeye salmon, it is important to determine if the rearing lakes produce smolts capable of surviving this migration. Until recently, researchers had ignored the effects of winter in many Pacific salmon systems, but we believe winter conditions could have a profound affect on salmon growth and survival. Alternate life histories (e.g., anadromy versus freshwater residency) are found in many salmonids; the fastest and slowest growing fish may remain in freshwater, and fish growing at average rates may migrate to sea (Nordeng 1983; Metcalfe 1998). Therefore, winter conditions also could affect life history strategy for some species. Under poor growth conditions, some individuals may delay migration until sufficient size and energy reserves are accumulated, and others may mature in freshwater (e.g., residual sockeye salmon).

Like kokanee, sockeye salmon growth is often density dependent and limited by food resources (Hyatt and Stockner 1985; Rieman and Meyers 1992). Monitoring programs in the Sawtooth Valley lakes have documented an inverse relationship between $O$. nerka abundance and zooplankton biomass (Taki and Mikkelsen 1997). Food limitation may be exacerbated during winter, when low under-ice temperatures and light intensities limit phytoplankton and zooplankton production (Steinhart 1997; Steinhart and Wurtsbaugh 1999). The combination of low zooplankton density and low light intensities during periods of ice cover may have restricted $O$. nerka foraging ability to such an extent that they were unable to meet the daily maintenance ration on some days (Steinhart and Wurtsbaugh 1999). During ice-covered periods in Stanley Lake, kokanee grew more and predicted consumption was higher when zooplankton were most abundant.

Therefore, winter conditions should be considered in recovery strategies, especially because the long seaward migration of Snake River sockeye salmon necessitates that they leave the nursery lakes physiologically prepared for migration to the ocean. For example, Chinook salmon smolts in the 
Columbia River depleted their available lipid reserves after traveling only $370 \mathrm{~km}$ (Rondorf et al. 1985). In other salmon populations, survival during migration and after arrival at sea has been related to the size or lipid content of the smolts (Bilton et al. 1982; Holtby et al. 1990; Henderson and Cass 1991). Rondorf et al. (1985) found that a $1 \%$ increase in starting lipid stores in Chinook salmon smolts resulted in nearly an $8 \%$ increase in survival.

Many sockeye salmon nursery lakes are constantly changing due to environmental and anthropogenic effects. Because seaward migrations can be stressful and energetically expensive, changes in winter conditions that influence growth may result in smolts experiencing different survival rates after migration. For example, Redfish Lake in the Sawtooth Valley was stocked with sockeye salmon fry from a broodstock program in 1994. Assuming that stocking increased O. nerka densities, competition for zooplankton may have increased, especially during winter when foraging is already limited. If increased competition exacerbates energetic losses during winter, sockeye salmon may be smaller and have fewer lipids, thus reducing migration survival. Alternatively, some individuals may delay migration for a year or forego migration and residualize. To improve rearing conditions in Redfish Lake, the lake was fertilized to increasing zooplankton abundance and biomass (Taki and Mikkelsen 1997; Wurtsbaugh et al. 1997). Our results suggest that monitoring of smolt size, lipid content, and additional research on the metabolic demands of the seaward migration would provide additional insights into the restoration efforts in the Sawtooth Valley, and that it may be prudent to consider winter conditions in other salmonid systems.

\section{Growth Metrics}

Different measures of kokanee growth in Stanley Lake highlight the ambiguity of growth measurements, reinforcing the need for proper choice of a growth metric for fishes. Changes in kokanee lengths and weights did not reflect changes in condition factor, lipid content, or estimated energetic content. Wet weight may provide misleading growth estimates because fish can replace tissue with water and experience no loss of weight, even though energy content decreases (Brett et al. 1969; Busacker et al. 1990). In lieu of measuring changes in length or weight, many researchers have turned to one of several measures for condition (Anderson and Neumann 1996). But condition factors based on length and weight can be misleading even if population-specific coefficients are used in the calculations (Cone 1989). Unless a researcher is explicitly interested in changes in weight or length (e.g., for the purpose of calculating swimming velocity or the time a fish may outgrow predators), then the goal is usually to reveal changes in fish energetic content. Length and weight measurements alone will not consistently reveal whether fish are gaining or losing calories. We suggest that the most appropriate way to measure fish growth is measuring energetic content directly by proximate or calorimetric analysis (Busacker et al. 1990) with corrections for size biases (Sutton et al. 2000). Because these processes are often time consuming and expensive, regressions of percent lipid or caloric density to percent water, such as those presented here and in Thompson et al. (1991), can provide an inexpensive and rapid way to estimate lipid content or caloric density. Alternatively, some researchers have successfully estimated lipid content with total body electrical conductivity estimates (Gillooly and Baylis 1999), nonlethal tissue samples (Hendry and Berg 1999), RNA-DNA ratios (Bulow et al. 1981), or multiple morphometric parameters (Adams et al. 1995). These latter methods are especially useful, as they are nondestructive methods that can be repeatedly used on the same fish through time.

\section{Acknowledgments}

We would like to thank all those people who helped collect the data necessary for this project. Odette Brandt, Michelle Gregg, Chad Mellison, Fredrick Norrsell, Rick Orme, John Ossowski, Mike Slater, and Darek Staab were all generous enough to help on many cold days and nights. We would also like to thank Dave Beauchamp, Phaedra Budy, Howard Gross, and Chris Luecke for sharing their data and discussing issues facing the recovery of the Snake River sockeye salmon. Special thanks to Doug Taki, David Teuscher, and Paul Kline for help in the field, sharing of data, and discussions of salmon ecology. Roy Stein, Grace Kilbane, Håkkan Turesson, Melo Maiolie, Patrick Martinez, and Bruce Shepard all provided thoughtful comments that improved the quality of this manuscript. Funding for this project came from Utah State University, the Shoshonne-Bannock Indian Tribes (through Bonneville Power Administration project 91-71), and the Ohio State University. 


\section{References}

Adams, C. E., F. A. Huntingford, and M. Jobling. 1995. A non-destructive morphometric technique for the estimation of body and mesenteric lipid in Artic charr: a case study of its application. Journal of Fish Biology 47:82-90.

Anderson, R. O., and R. M. Neumann. 1996. Length, weight, and associated structural indices. Pages 447-482 in B. R. Murphy and D. W. Willis, editors. Fisheries techniques. American Fisheries Society, Bethesda, Maryland.

Beauchamp, D. A., D. J. Stewart, and G. L. Thomas. 1989. Corroboration of a bioenergetics model for sockeye salmon. Transactions of the American Fisheries Society 118:597-607.

Berglund, I. 1995. Effects of size and spring growth on sexual maturation in $1+$ Atlantic salmon (Salmo salar) male parr: interactions with smoltification. Canadian Journal of Fisheries and Aquatic Sciences 52:2682-2694.

Bilton, H. T., D. F. Alderdice, and J. T. Schnute. 1982. Influence of time and size at release of juvenile coho salmon (Oncorhynchus kisutch) on returns at maturity. Canadian Journal of Fisheries and Aquatic Sciences 39:426-447.

Bjornn, T. C., D. R. Craddock, and D. R. Corley. 1968. Migration and survival of Redfish Lake, Idaho, sockeye salmon, Oncorhynchus nerka. Transactions of the American Fisheries Society 97:360-373.

Bligh, E. G., and W. J. Dyer. 1959. A rapid method of total lipid extraction and purification. Journal of Biochemical Physiology 37:911-917.

Brett, J. R., J. E. Shelbourn, and C. T. Shoop. 1969. Growth rate and body composition of fingerling sockeye salmon, Oncorhynchus nerka, in relation to temperature and ration size. Journal of the Fisheries Research Board of Canada 26:2363-2394.

Budy, P., G. P. Thiede, N. Bouwes, C. E. Petrosky, and H. Schaller. 2002. Evidence linking delayed mortality of Snake River sockeye salmon to their earlier hydrosystem experience. North American Journal of Fisheries Management 22:35-51.

Bulow, F. J., M. E. Zeman, R. J. Winningham, and W. F. Hudson. 1981. Seasonal variations in RNA-DNA ratios and in indicators of feeding, reproduction, energy storage, and condition factor in a population of bluegill, Lepomis macrochirus Rafinesque. Journal of Fish Biology 18:237-244.

Burgner, R. L. 1992. Life history of sockeye salmon (Oncorhynchus nerka). Pages 1-117 in C. Groot and L. Margolis, editors. Pacific salmon life histories. University of British Columbia Press, Vancouver.

Busacker, G. P., I. R. Adelman, and E. M. Goolish. 1990. Growth. Pages 363-387 in C. B. Shreck and P. B. Moyle, editors. Methods for fish biology. American Fisheries Society, Bethesda, Maryland.

Cone, R. S. 1989. The need to reconsider the use of conidition indices in fisheries science. Transactions of the American Fisheries Society 118:510-514.

Cunjak, R. A. 1988. Physiological consequences of overwintering in streams: the cost of acclimatiza- tion? Canadian Journal of Fisheries and Aquatic Sciences 45:443-452.

Dannewitz, J., and E. Petersson. 2001. Association between growth, body condition and anti-predator behaviour in maturing and immature brown trout parr. Journal of Fish Biology 59:1081-1091.

Duston, J., and R. L. Saunders. 1999. Effect of winter food deprivation on growth and sexual maturity of Atlantic salmon (Salmo salar) in seawater. Canadian Journal of Fisheries and Aquatic Sciences 56:201207.

Eggers, D. M. 1978. Limnetic feeding behavior of juvenile sockeye salmon in Lake Washington and predator avoidance. Limnology and Oceanography 23:1114-1125.

Foote, C. J., I. Mayer, C. C. Wood, W. C. Clarke, and J. Blackburn. 1994. On the developmental pathway to nonanadromy in sockeye salmon, Oncorhynchus nerka. Canadian Journal of Zoology 72:397-405.

Foote, C. J., C. C. Wood, W. C. Clarke, and J. Blackburn. 1992. Circannual cycle of seawater adaptability in Oncorhynchus nerka: genetic differences between sympatric sockeye salmon and kokanee. Canadian Journal of Fisheries and Aquatic Sciences 49:99109.

Foote, C. J., C. C. Wood, and R. E. Withler. 1989. Biochemical genetic comparison of sockeye salmon and kokanee, the anadromous and nonanadromous forms of Oncorhynchus nerka. Canadian Journal of Fisheries and Aquatic Sciences 46:149-158.

Gillooly, J. F., and J. R. Baylis. 1999. Reproductive success and the energetic cost of parental care in male smallmouth bass. Journal of Fish Biology 54: 573-584.

Gross, H. P., W. A. Wurtsbaugh, and C. Luecke. 1998. The role of anadromous sockeye salmon in the nutrient loading and productivity of Redfish Lake, Idaho. Transactions of the American Fisheries Society 127:1-18.

Henderson, M. A., and A. J. Cass. 1991. Effect of smolt size on smolt-to-adult survival for Chilko Lake sockeye salmon (Oncorhynchus nerka). Canadian Journal of Fisheries and Aquatic Sciences 48:988994.

Henderson, P. A., R. H. A. Holmes, and R. N. Bamber. 1988. Size-selective overwintering mortality in the sand smelt, Atherina boyeri Risso, and its role in population regulation. Journal of Fish Biology 33: 221-233.

Hendry, A. P., and O. K. Berg. 1999. Secondary sexual characters, energy use, senescence, and the cost of reproduction in sockeye salmon. Canadian Journal of Zoology 77:1663-1675.

Hewett, S. W., and B. L. Johnson. 1992. A generalized bioenergetics model of fish growth for microcomputers. University of Wisconsin Sea Grant Institute, UW Sea Grant Technical Report WIS-SG-92-250, Madison.

Hoar, W. S. 1976. Smolt transformation: evolution, behavior, and physiology. Journal of the Fisheries Research Board of Canada 33:1234-1252.

Holm-Hansen, O., and B. Riemann. 1978. Chlorophyll 
$a$ determination: improvements in methodology. Oikos 30:438-447.

Holtby, L. B., B. C. Andersen, and R. K. Kadowaki. 1990. Importance of smolt size and early ocean growth to interannual variability in marine survival of coho salmon (Oncorhynchus kisutch). Canadian Journal of Fisheries and Aquatic Sciences 47:21282194.

Hubert, W. A. 1996. Passive capture techniques. Pages 157-192 in B. R. Murphy and D. W. Willis, editors. Fisheries techniques. American Fisheries Society, Bethesda, Maryland.

Hyatt, K. D., and J. G. Stockner. 1985. Responses of sockeye salmon (Oncorhynchus nerka) to fertilization of British Columbia coastal lakes. Canadian Journal of Fisheries and Aquatic Sciences 42:320331.

Jobling, M., and I. Miglavs. 1993. The size of lipid depots-a factor contributing to the control of food intake in Arctic charr, Salvelinus alpinus? Journal of Fish Biology 43:487-489.

Jonsson, N., and B. Jonsson. 1998. Body composition and energy allocation in life-history stages of brown trout. Journal of Fish Biology 53:1306-1316.

Kadri, S., D. F. Mitchell, N. B. Metcalfe, F. A. Huntingford, and J. E. Thorpe. 1996. Differential patterns of feeding and resource accumulation in maturing and immature Atlantic salmon, Salmo salar. Aquaculture 142:245-257.

Kerr, D. C., C. D. Ankney, and J. S. Millar. 1982. The effect of drying temperature on extraction of petroleum ether soluble fats of small birds and mammals. Canadian Journal of Zoology 60:470-472.

Koenings, J. P., J. E. Edmundson, G. B. Kyle, and J. M. Edmundson. 1987. Limnological field and laboratory manual: methods for assessing aquatic production. Alaska Department of Fish and Game, Fisheries Rehabilitation, Enhancement, and Development Division Report 71, Juneau.

Leonard, J. B. K., and S. D. McCormick. 1999. Effects of migration distance on whole-body and tissuespecific energy use in American shad (Alosa sapidissima). Canadian Journal of Fisheries and Aquatic Sciences 56:1159-1171.

Ludsin, S. A., and D. R. DeVries. 1997. First-year recruitment of largemouth bass: the interdependency of early life history stages. Ecological Applications 7:1024-1038.

Maclean, A., and N. B. Metcalfe. 2001. Social status, access to food, and compensatory growth in juvenile Atlantic salmon. Journal of Fish Biology 58: 1331-1346.

McCauley, E. 1984. The estimation of the abundance and biomass of zooplankton in samples, Pages 228 265 in J. A. Downing and F. Rigler, editors. A manual on methods of secondary productivity in freshwaters. Blackwell Scientific Publications, Oxford, UK.

Metcalfe, N. B. 1998. The interaction between behavior and physiology in determining life history patterns in Atlantic salmon (Salmo salar). Canadian Journal of Fisheries and Aquatic Sciences 55(Supplement 1):93-103.

Metcalfe, N. B., and J. E. Thorpe. 1992. Anorexia and defended energy levels in over-wintering juvenile salmon. Journal of Animal Ecology 61:175-181.

Miranda, L. E., and W. D. Hubbard. 1994. Length-dependent winter survival and lipid composition of age-0 largemouth bass in Bay Springs Reservoir, Mississippi. Transactions of the American Fisheries Society 123:80-87.

Morgan, I. J., I. D. McCarthy, and N. B. Metcalfe. 2000. Life-history strategies and protein metabolism in overwintering juvenile Atlantic salmon: growth is enhanced in early migrants through lower protein turnover. Journal of Fish Biology 637-647.

Nordeng, H. 1983. Solution to the "char problem" based on Arctic char (Salvelinus alpinus) in Norway. Canadian Journal of Fisheries and Aquatic Sciences 40:1372-1387.

Oliver, J. D., and G. F. Holeton. 1979. Overwinter mortality of fingerling smallmouth bass in relation to size, relative energy stores, and environmental temperature. Transactions of the American Fisheries Society 108:130-136.

Post, J. R., and D. O. Evans. 1989. Size-dependent overwinter mortality of young-of-the-year yellow perch (Perca flavescens): laboratory, in situ enclosure, and field experiments. Canadian Journal of Fisheries and Aquatic Sciences 46:1958-1968.

Quinn, T. P., E. Graynoth, C. C. Wood, and C. J. Foote. 1998. Genotypic and phenotypic divergence of sockeye salmon in New Zealand from their ancestral British Columbia populations. Transactions of the American Fisheries Society 127:517-534.

Reinhardt, U. G. 2002. Asset protection in juvenile salmon: how adding biological realism changes a dynamic foraging model. Behavioral Ecology 13: 94-100.

Rice, S. D., R. E. Thomas, and A. Moles. 1994. Physiological and growth differences in three stocks of underyearling sockeye salmon (Oncorhynchus ner$\mathrm{ka}$ ) on early entry to seawater. Canadian Journal of Fisheries and Aquatic Sciences 51:974-980.

Ricker, W. E. 1938. "Residual"' and kokanee salmon in Cultus Lake. Journal of the Fisheries Research Board of Canada 4:192-218.

Rieman, B. E., and D. L. Meyers. 1992. Influence of fish density and relative productivity on growth of kokanee in ten oligotrophic lakes and reservoirs in Idaho. Transactions of the American Fisheries Society 121:178-191.

Rikardsen, A. H., and J. M. Elliot. 2000. Variations in juvenile growth, energy allocation and life-history strategies of two populations of Arctic charr in North Norway. Journal of Fish Biology 56:328346.

Rondorf, D. W., M. S. Dutchuk, A. S. Kolok, and M. L. Gross. 1985. Bioenergetics of juvenile salmon during the spring outmigration. Bonneville Power Administration, Annual Report 1983, Project 82-11, Portland, Oregon.

Rowe, D. K., J. E. Thorpe, and A. M. Shanks. 1991. 
Role of fat stores in the maturation of male Atlantic salmon (Salmo salar) parr. Canadian Journal of Fisheries and Aquatic Sciences 48:405-413.

Ruggerone, G. T. 1992. Winter ecology of sockeye salmon in the Chignik Lakes. Fisheries Research Institute, University of Washington, Annual Report, Seattle.

Shuter, B. J., and J. R. Post. 1990. Climate, population viability, and the zoogeography of temperate fishes. Transactions of the American Fisheries Society 119: 314-336.

Silverstein, J. T., K. D. Shearer, W. W. Dickhoff, and E. M. Plisetskaya. 1999. Regulation of nutrient intake and energy balance in salmon. Aquaculture 177:1 61-169.

Slotte, A. 1999. Effects of fish length and condition on spawning migration in Norwegian spring spawning herring (Clupea harengus L.). Sarsia 84:111-127.

Sokal, R. R., and F. J. Rohlf. 1981. Biometry. Freeman, New York.

Steinhart, G. B. 1997. Winter limnology and the ecology of Oncorhynchus nerka in high-mountain lakes of Idaho. Master's thesis. Utah State University, Logan.

Steinhart, G. B., and W. A. Wurtsbaugh. 1999. Underice diel vertical migrations of Oncorhynchus nerka and their zooplankton prey. Canadian Journal of Fisheries and Aquatic Sciences 56(Supplement 1): 152-161.

Sutton, S. G., T. P. Bult, and R. L. Haedrich. 2000. Relationships among fat weight, body weight, water weight, and condition factors in wild Atlantic salmon. Transactions of the American Fisheries Society 129:527-538.

Svedäng, H., and H. Wickström. 1997. Low fat contents in female silver eels: indications of insufficient energetic stores for migration and gonadal development. Journal of Fish Biology 50:475-486.

Taki, D., and A. Mikkelsen. 1997. Snake River sockeye salmon habitat and limnological research. Bonne- ville Power Administration, Annual Report 1996, Project 91-71, Portland, Oregon.

Taylor, E. B., C. J. Foote, and C. C. Wood. 1996. Molecular genetic evidence for parallel life-history evolution within a Pacific salmon (sockeye salmon and kokanee, Oncorhynchus nerka). Evolution 50: 401-416.

Taylor, E. B., S. Harvey, S. Pollard, and J. Volpe. 1997. Postglacial genetic differentiation of reproductive ecotypes of kokanee (Oncorhynchus nerka) in Okanagan Lake, British Columbia. Molecular Ecology 6: 503-517.

Thompson, J. M., E. P. Bergersen, C. A. Carlson, and L. R. Kaeding. 1991. Role of size, condition, and lipid content in the overwinter survival of age-0 Colorado squawfish. Transactions of the American Fisheries Society 120:346-353.

Thorpe, J. E. 1987. Environmental regulation of growth patterns in juvenile Atlantic salmon. Pages 463-474 in R. C. Summerfelt and G. E. Hall, editors. Age and growth of fish. Iowa State University Press, Ames.

Toneys, M. L., and D. W. Coble. 1979. Size-related, first winter mortality of freshwater fishes. Transactions of the American Fisheries Society 108:415-419.

Venditti, D. A., D. W. Rondorf, and J. M. Kraut. 2000. Migratory behavior and forebay delay of radiotagged juvenile fall chinook salmon in a lower Snake River impoundment. North American Journal of Fisheries Management 20:41-52.

Wurtsbaugh, W. A., H. P. Gross, C. Luecke, and P. Budy. 1997. Nutrient limitation of oligotrophic sockeye salmon lakes of Idaho (USA). Internationale Vereinigung für theoretische und angewandte Limnologie Verhandlungen 26:413-419.

Wood, C. C., C. J. Foote, and D. T. Rutherford. 1999. Ecological interactions between juveniles of reproductively isolated anadromous and non-anadromous morphs of sockeye salmon, Oncorhynchus nerka, sharing the same nursery lake. Environmental $\mathrm{Bi}$ ology of Fishes 54:161-173. 